\title{
Calotrope (Calotropis procera) control
}

\author{
Joseph Vitelli ${ }^{\mathrm{A}, \mathrm{E}}$, Barbara Madigan $^{\mathrm{B}}$, Peter Wilkinson ${ }^{\mathrm{C}}$ and Peter van Haaren ${ }^{\mathrm{D}}$ \\ ABiosecurity Queensland, Queensland Department of Primary Industries and Fisheries (QDPIF), \\ PO Box 36, Sherwood, Qld 4075, Australia. \\ ${ }^{B}$ Biosecurity Queensland, QDPIF, PO Box 187, Charters Towers, Qld 4820, Australia. \\ CPlant Science, QDPIF, PO Box 2282, Toowoomba, Qld 4350, Australia. \\ D397 Palmerston Hwy, Innisfail, Qld 4860, Australia. \\ ${ }^{\mathrm{E} C}$ Corresponding author. Email: joseph.vitelli@dpi.qld.gov.au
}

\begin{abstract}
Calotrope [Calotropis procera (Aiton) W.T.Aiton] is an exotic shrub or small tree species that is currently invading the tropical savannahs of northern Australia. A chemical trial involving 11 herbicides and four application methods (foliar, basal bark, cut stump and soil applied) was undertaken to identify effective chemicals to control calotrope. Of the foliar herbicides tested, imazapyr provided $100 \%$ mortality at the rates applied, and the higher rate of metsulfuron-methyl killed $100 \%$ of the treated plants. The herbicides 2,4-D butyl ester, fluroxypyr, triclopyr and triclopyr/picloram killed greater than $80 \%$ of the plants when applied by a basal bark or cut stump (when cut $5 \mathrm{~cm}$ above ground level) method of application. Plants cut close to ground level $(5 \mathrm{~cm})$ were controlled more effectively than plants cut $20 \mathrm{~cm}$ above ground level.

Chemical control (foliar and cut stump spraying) is a cost effective tool to treat calotrope densities $<800$ plants $/$ ha. Adoption of pasture management practices that promote perennial grasses, in conjunction with strategic chemical control, would further increase the effectiveness and reduce the costs of controlling vast areas of this weed.
\end{abstract}

Additional keywords: chemical, cut stump, rangelands, spraying.

\section{Introduction}

Calotrope [Calotropis procera (Aiton) W.T.Aiton], a member of the Asclepiadaceae, is native to tropical and subtropical Africa and Asia (Rahman and Wilcock 1991), and is common in the Middle East (Grace 2006). It is now naturalised in Central and South America, the Caribbean islands, Indonesia, Mexico and many Pacific islands. In Australia, infestations are found across northern Australia and in northern South Australia (Thorp and Lynch 2000; Parsons and Cuthbertson 2001; Grace 2006).

Calotrope is a spreading shrub or small tree growing $2-6 \mathrm{~m}$ in height. It has a waxy appearance and a milky latex sap. The stems are single or branching (often from near ground level), grey-green and smooth, though older stems have a soft thick corky bark. The plant's root system consists of a 3-4 m taproot, with spreading woody laterals. The root system, also containing the milky latex, forms adventitious shoots when injured (Parsons and Cuthbertson 2001).

In the tropics, calotrope seeds germinate with the onset of the wet season (Grace 2006). Growth is rapid during the wet months of the year, decreasing in the dry season (Grace 2006). It appears that the age at first flowering is at least 2 years, with flowers emerging in winter (Parsons and Cuthbertson 2001). In established plants, the wet season also promotes new growth, including suckering from roots (Parsons and Cuthbertson 2001). Dispersal of calotrope seeds is mainly by wind and water (Grace 2006). Infestations increase in size and density both by suckering from roots and crown, and by seedlings germinating from seeds dropped near the parent plants (Parsons and Cuthbertson 2001).

Though calotrope is reputed to be toxic to stock, few deaths have been reported in Australia. Abbas et al. (1992) conducted preliminary studies into the use of calotrope as animal feed. The results showed that shade-dried calotrope leaves contained $19.6 \%$ crude protein. In palatability trials, when goats were fed dry calotrope leaves only, they would consume no more than $0.25-0.5 \mathrm{~kg}$ of the leaves. However, when the leaves were mixed with hay, goats consumed mixtures containing up to $50 \%$ dry calotrope leaves (Abbas et al. 1992). In small scale trials in Australia, feeding calotrope leaves and flowers with hay to cattle and sheep produced no ill effects (Radunz et al. 1984). Cattle and goats have also been seen to extensively graze calotrope in the dry season (July-November), with no ill effects (Radunz et al. 1984; Foran et al. 1985; Parsons and Cuthbertson 2001; Grace 2006).

Despite its possible benefits, calotrope is a growing problem in Australia. The plant forms dense thickets, particularly on alluvial flats along rivers. It can then spread into adjacent pastures where it reduces grazing value and can make mustering difficult (Meadley 1971; Parsons and Cuthbertson 2001). Once established, dense infestations are difficult and uneconomical to control (Grace 2006). Small colonies or individual calotrope plants may be controlled by grubbing, if at least $25-30 \mathrm{~cm}$ of the taproot and as many laterals as possible are removed (Parsons and Cuthbertson 2001). The use of shallow ploughs, however, will contribute to 
extensive regrowth from the plant's spongy tuberous root system (Grace 2006). Similar regrowth is encountered with cool burns. The lack of fuel under dense calotrope stands prevents the establishment of hot fires that are required for effective control (Parsons and Cuthbertson 2001; Grace 2006). In Australia, calotrope is not targeted for biological control. However, fungal pathogens from Brazil have been suggested as possible biological control agents for calotrope (Ellison and Barret 2004). A pathogen, Passalora calotropidis (Ellis \& Everh.) U.Braun, was recently found on calotrope in north Queensland, where it was associated with a damaging leaf spot disease, causing partial or total defoliation and tip and stem dieback (Wilkinson et al. 2005).

In a long-term grazing exclusion study in the Northern Territory, Bastin et al. (2003) reported a decline in calotrope growing on red calcareous soils and attributed it to a combination of competition from perennial grasses [Heteropogon contortus (L.) Roem. \& Schult. (bunch speargrass) and Dichanthium spp.], and a series of below average rainfall in the wet season (October-April). Wet season rainfall at the site was, on average, 14\% lower during the wet seasons from 1979 to 1989 (median wet season rainfall during 1969 to 2002 was $749 \mathrm{~mm}$ ) (Bastin et al. 2003). Light to moderate stocking rates $\left(5-7 \mathrm{head} / \mathrm{km}^{2}\right)$ allowed the above-ground biomass of perennial and annual grasses to increase, respectively, to 475 and $450 \mathrm{~kg}$ dry weight/ha. At the same study site, Foran et al. (1985) observed calotrope establishment and dominance from 1974 to 1978 in an area predominately of bare soil and a sparse covering of annual grasses (445 kg/ha) [Enneapogon caerulescens (Gaudich.) N.T.Burb (limestone grass), Brachyachne convergens (F.Muell.) Stapf. (spider grass), Sporobolus australasicus Domin, and Aristida spp. (fairy grass)] and perennial grasses ( $80 \mathrm{~kg} / \mathrm{ha})$. By 1978 , calotrope had reached 1000 stems/ha in enclosures and 200 stems/ha in areas grazed by cattle (Foran et al. 1985). The establishment and increase in calotrope was attributed to above average wet season rainfall (the site averaged $11 \%$ higher than the long-term median) and an absence of perennial grasses (Foran et al. 1985; Bastin et al. 2003). Paddocks dominated by the tufted perennial grass Cenchrus ciliaris L. (buffel grass) can reduce the establishment of herbaceous species (Jackson 2005) including Parthenium hysterophorus L. (O'Donnell and Adkins 2005) and inhibit the growth of calotrope (Cheam 1984a, 1984b). However, buffel grass can become a problem itself, particularly in conservation areas (McIvor 2003; Clarke et al. 2005; Jackson 2005; Grace 2006).

There are no chemicals currently registered for chemical control of calotrope. This paper reports on studies to identify effective chemicals that can be applied to control calotrope plants.

\section{Materials and methods}

Study sites

Separate field experiments were initiated in May 1989 and February 2003 to determine the effect of basal bark, cut stump, soil and foliar applied herbicides on calotrope plants growing in the Gulf plains of north Queensland. The wet season in the Gulf plains is from November to March, with $90 \%$ of the annual rainfall falling during this period (Bureau of Meteorology 2007). All treatments (other than soil applied) were applied to individual plants that were actively growing and $0.2-5 \mathrm{~m}$ high. Calotrope density at the sites averaged 2500 plants/ha.

Experiment A was conducted on a property $\left(17^{\circ} 12^{\prime} 01^{\prime \prime} \mathrm{S}\right.$, $141^{\circ} 42^{\prime} 00^{\prime \prime} \mathrm{E}$ ) located $80 \mathrm{~km}$ north-east of Normanton. The mean annual rainfall at the site during the study period (1989-91) was $1032 \pm 422 \mathrm{~mm} /$ year with a large inter-annual variability. The number of rainy days/year was, on average, $92 \pm 6$ (Table 1 ). The soil type was heavy grey and brown cracking clay. The vegetation was tree and shrub savannah with a grass layer dominated by the annual grass Aristida contorta (F.Muell.) (bunched kerosene grass) and perennial grasses Dichanthium sericeum [(R.Br.) A.Camus] (blue grass), Heteropogon contortus [(L.) Roem. \& Schult.] (black spear grass), Chrysopogon fallax (S.T.Blake) (golden beard grass), Astrebla squarrosa (C.E.Hubb.) (bull mitchell grass), Dichanthium fecundum (S.T.Blake) (curly bluegrass) and Eulalia aurea [(Bory) Kunth] (browntop). The shrub stratum was dominated by calotrope and Cryptostegia grandiflora (Roxb. ex R.Br.) (rubber vine) while a mixture of Eucalyptus leptophleba (F.Muell.) (Molloy red box), Corymbia polycarpa [(F. Muell.) K.D. Hill \& L.A.S. Johnson] (bloodwood), Lysiphyllum cunninghamii [(Benth.) de Wit] (bauhinia) and Erythrophleum chlorostachys [(F.Muell.) Baill] (ironwood) dominated the tree stratum.

Calotrope plants at this site were treated with basal bark, cut stump, soil and foliar applied herbicides. Each treatment contained 10 plants replicated three times in a complete randomised block design.

Experiment B was on a property $\left(18^{\circ} 16^{\prime} 43^{\prime \prime} \mathrm{S}, 143^{\circ} 10^{\prime} 53^{\prime \prime} \mathrm{E}\right)$ $35 \mathrm{~km}$ west of Georgetown. The mean annual rainfall for the study period (2003-04) at the site was $686 \pm 47 \mathrm{~mm} /$ year and the number of rainy days/year averaged $86 \pm 16$ (Table 1). Soils were fine sands and alluvial soils. The herbaceous vegetation at the site consisted of Hyptis suaveolens [(L.) Poit.] (hyptis) and a few grasses including Heteropogon contortus, Themeda triandra (Forssk.) (kangaroo grass) and Sarga plumosum [(R.Br.) Spangler] (plume sorghum). The shrub stratum was dominated by calotrope, Ziziphus mauritiana (Lam.) (chinee apple), Ricinus communis (L.) (castor oil) and Cryptostegia grandiflora, and a mixture of Eucalyptus leptophleba, Corymbia polycarpa, Eucalyptus melanophloia (F.Muell.) (silver-leaved ironbark) and Corymbia dallachiana (Benth.) (ghost gum) dominated the tree stratum.

Only basal bark and cut stump treatments were applied to calotrope plants growing at this site. The experiment was a $2 \times 11$

Table 1. Mean annual rainfall and number of rainy days $(\geq 0.1 \mathrm{~mm})$ measured at the experimental sites during the study periods

\begin{tabular}{lccc}
\hline Site & Year & $\begin{array}{c}\text { Rainfall } \\
\text { (mm/year) }\end{array}$ & $\begin{array}{c}\text { Number of rainy } \\
\text { days/year }\end{array}$ \\
\hline Experiment A & 1989 & 1010 & 98 \\
& 1990 & 622 & 92 \\
& 1991 & 1465 & 87 \\
Experiment B & Mean & 1032 & 92 \\
& Standard deviation & 422 & 6 \\
& 2003 & 719 & 73 \\
& 2004 & 653 & 96 \\
& Mean & 686 & 86 \\
& Standard deviation & 47 & 16 \\
\hline
\end{tabular}


factorial replicated three times using a complete randomised design. Factor A was the two methods of application (basal bark and cut stump method) assigned to the mainplots, and factor B was the 11 herbicide treatments assigned to the subplots. Each replicate contained 20 plants.

\section{Measurements}

The two experiments evaluated a total of 11 herbicides at various concentrations (Table 2). Rates selected were based on label recommendations for control of other shrub species. All plants were measured for height and basal diameter (at ground level) before treatment, and the number of stems per plant within the treated population was also counted. Plants in Experiment B were also separated into seven basal diameter size classes (21-48, 49-62, 63-73, 74-87, 88-100, 101-119, and 120-166 mm). The mean basal diameter of plants treated in Experiment A and Experiment B was $46.4 \mathrm{~mm}$ (s.e.m. $=0.6$ ) and $69.4 \mathrm{~mm}$ (s.e.m. $=0.65)$, respectively. At final assessment (737 days after treatment for Experiment A and 556 days after treatment for Experiment B) the main stem and taproot of plants recorded as dead were cut and visually assessed to ensure no live tissue remained.

\section{Spray equipment and application}

\section{Foliar application}

A 20-L, 12-V electric powered back-carried spray unit with an adjustable solid cone nozzle and operating pressure of $200 \mathrm{kPa}$ was used to apply herbicides for the foliar treatments in Experiment A. Each plant was sprayed to the point where the spray mixture dripped from the foliage. All solutions contained $0.2 \%(\mathrm{v} / \mathrm{v})$ non-ionic surfactant (BS1000).

\section{Basal bark application}

An 8-L handheld pneumatic sprayer with a $0.6 \mathrm{~m}$ wand and an adjustable full-cone nozzle and an operating pressure of $70 \mathrm{kPa}$

Table 2. Herbicides and dose rates tested on calotrope

Herbicide costing per $100 \mathrm{~L}$ of spray solution based on retail prices for November 2007

\begin{tabular}{|c|c|c|c|c|}
\hline Method of application & $\begin{array}{l}\text { Herbicide (active } \\
\text { ingredient) }\end{array}$ & Trade name & $\begin{array}{c}\text { Rates applied } \\
\text { (g active ingredient/ } \\
\text { 100 L spray solution) }\end{array}$ & $\begin{array}{l}\text { Cost }(\$) / 100 \mathrm{~L} \\
\text { spray solution }\end{array}$ \\
\hline \multirow[t]{17}{*}{ Foliar applied $^{\mathrm{A}}$} & 2,4-D/picloram & \multirow[t]{3}{*}{ Tordon 75-D } & $100 / 25$ & 17.43 \\
\hline & 2,4-D/picloram & & $200 / 50$ & 32.00 \\
\hline & 2,4-D/picloram & & $400 / 100$ & 61.15 \\
\hline & Clopyralid & \multirow[t]{3}{*}{ Lontrel L } & 150 & 33.10 \\
\hline & Clopyralid & & 300 & 63.35 \\
\hline & Clopyralid & & 600 & 123.85 \\
\hline & Dicamba & Dicamba & 200 & 19.13 \\
\hline & Fluroxypyr & \multirow[t]{3}{*}{ Starane 200} & $150^{\mathrm{C}}$ & 21.41 \\
\hline & Fluroxypyr & & $300^{\mathrm{C}}$ & 39.98 \\
\hline & Fluroxypyr & & $600^{\mathrm{C}}$ & 77.10 \\
\hline & Imazapyr & \multirow[t]{2}{*}{ Arsenal 250 Herbicide } & 125 & 57.28 \\
\hline & Imazapyr & & 250 & 111.71 \\
\hline & Metsulfuron-methyl & \multirow[t]{2}{*}{ Brush-Off } & 9 & 5.33 \\
\hline & Metsulfuron-methyl & & 12 & 6.15 \\
\hline & Triclopyr/picloram & \multirow[t]{3}{*}{ Grazon DS } & $50.1 / 16.7$ & 8.59 \\
\hline & Triclopyr/picloram & & $75 / 25$ & 11.45 \\
\hline & Triclopyr/picloram & & $150 / 50$ & 20.04 \\
\hline \multirow[t]{2}{*}{ Soil applied } & Tebuthiuron & \multirow[t]{2}{*}{ Graslan } & $1500 \mathrm{~g} / \mathrm{ha}$ & $143.22 / \mathrm{ha}$ \\
\hline & Tebuthiuron & & $2000 \mathrm{~g} / \mathrm{ha}$ & $190.96 / \mathrm{ha}$ \\
\hline \multirow[t]{15}{*}{ Basal bark/cut stump ${ }^{\mathrm{B}}$} & 2,4-D butyl ester & \multirow[t]{4}{*}{ AF Rubber Vine Spray } & 1000 & 146.12 \\
\hline & 2,4-D butyl ester & & 2000 & 167.94 \\
\hline & 2,4-D butyl ester & & 4000 & 211.59 \\
\hline & 2,4-D butyl ester & & 8000 & 298.87 \\
\hline & Fluroxypyr & \multirow[t]{5}{*}{ Starane 200} & $300^{\mathrm{C}}$ & 159.56 \\
\hline & Fluroxypyr & & 333 & 163.44 \\
\hline & Fluroxypyr & & 500 & 183.07 \\
\hline & Fluroxypyr & & $600^{\mathrm{C}}$ & 194.82 \\
\hline & Fluroxypyr & & 1000 & 241.84 \\
\hline & Triclopyr & \multirow[t]{2}{*}{ Garlon 600} & 480 & 153.01 \\
\hline & Triclopyr & & 960 & 181.71 \\
\hline & Triclopyr/picloram & \multirow[t]{4}{*}{ Access } & $100 / 50$ & 151.69 \\
\hline & Triclopyr/picloram & & $200 / 100$ & 179.09 \\
\hline & Triclopyr/picloram & & $400 / 200$ & 233.88 \\
\hline & Control & & Neat diesel & 124.30 \\
\hline
\end{tabular}

${ }^{\mathrm{A}}$ Foliar applied herbicides diluted with water.

${ }^{\mathrm{B}}$ Basal bark/cut stump applied herbicide diluted with diesel (cost of diesel based on $\$ 1.24 / \mathrm{L}$ ).

${ }^{\mathrm{C}}$ Fluroxypyr formulation was $300 \mathrm{~g}$ a.i./L. 


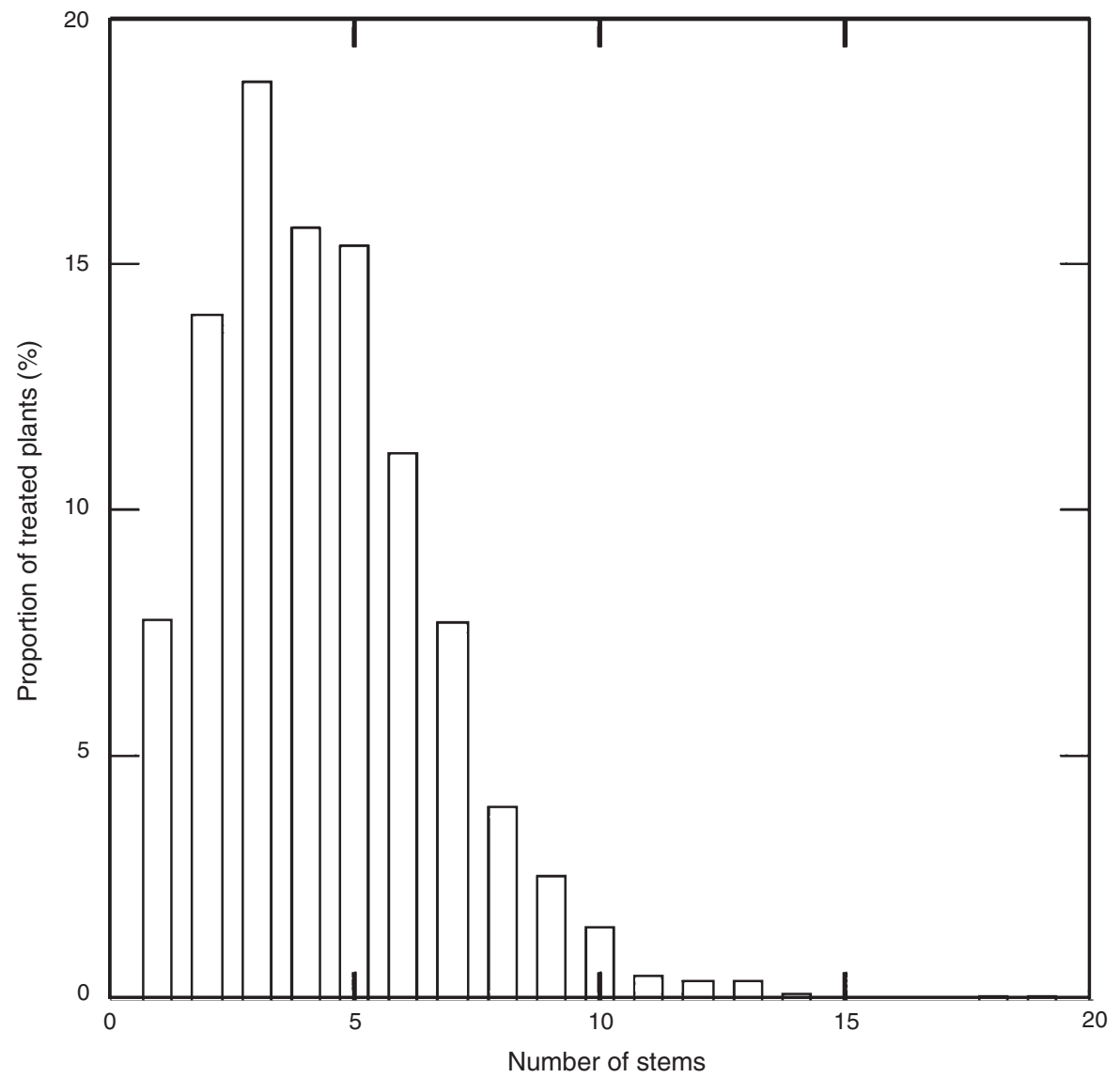

Fig. 1. Proportion of plants treated compared with number of stems per plant.

was used to deliver the herbicide spray mix to the entire circumference of the lower $40 \mathrm{~cm}$ of each plant stem.

\section{Cut stump application}

An 8-L handheld pneumatic sprayer (operating pressure of $70 \mathrm{kPa}$ ) with a $0.6 \mathrm{~m}$ wand and a variable full-cone nozzle was used to deliver the herbicide spray mix to freshly cut stumps. The herbicide spray mix was applied to the entire freshly cut surface of each stem within $30 \mathrm{~s}$ of the stems being cut. Plants in Experiment A were cut with a bow saw to a height of $20 \mathrm{~cm}$, and plants in Experiment B were cut with a brush-cutter to a height of $5 \mathrm{~cm}$ above ground level. The portable Stihl FS550 (BadenWürttemberg, Stuttgart, Germany) brush-cutter developed $2.8 \mathrm{~kW}$ of power and weighed $11 \mathrm{~kg}$. A fuel capacity of $0.76 \mathrm{~L}$ provided $\sim 50 \mathrm{~min}$ of operational cutting time before refuelling, enabling $450 \mathrm{stems} / \mathrm{h}$ to be treated using this method.

\section{Soil applied}

Tebuthiuron pellets ( $20 \%$ formulation) were evenly broadcast by hand to $10 \times 10 \mathrm{~m}$ plots at application rates of 1.5 and $2.0 \mathrm{~kg}$ active ingredient (a.i.)/ha.

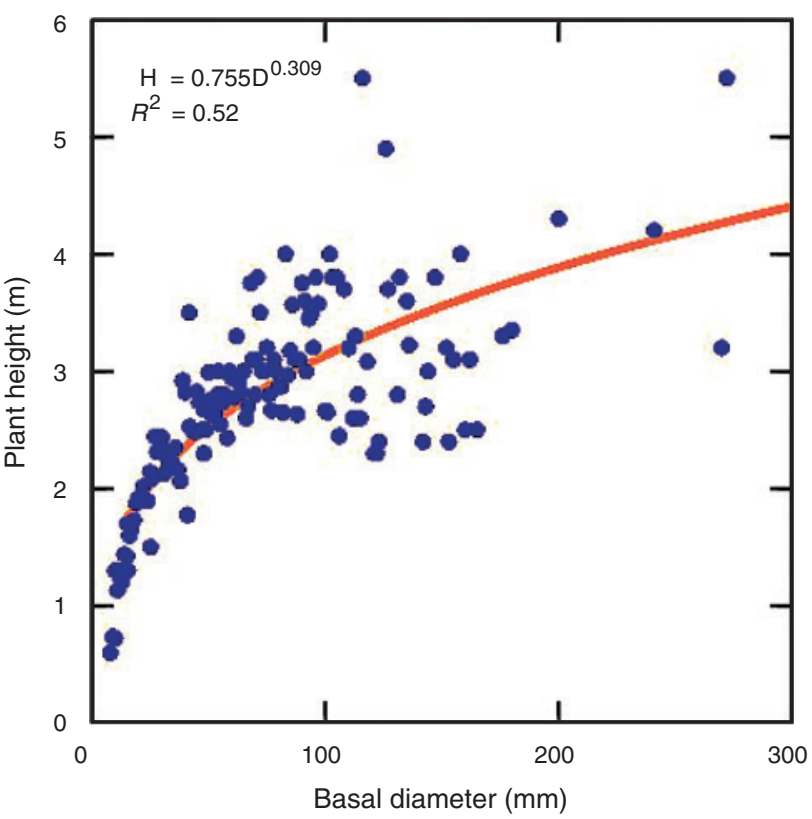

Fig. 2. Relationship between calotrope basal diameter and plant height. 


\section{Treatment costs}

To assist in determining the costs of treating calotrope infested paddocks with various control techniques, five additional plots with varying calotrope densities $(100,200,400,800$ and 1600 plants/ha) were foliar sprayed with a $12-\mathrm{V}$ electric powered spray unit (to the point of run-off $\sim 1500 \mathrm{~L} / \mathrm{ha}$ ), treated with a soil applied herbicide, basal barked and cut stumped. Following a grid pattern, the soil applied herbicides were hand broadcast and uniformly applied to cover only the calotrope canopy area from the base of each plant to $30 \mathrm{~cm}$ beyond the drip line. A total of 15 plots were treated with each density replicated three times. Both labour and volume of herbicide used for each density was recorded. The labour and volume of herbicide required to control individual calotrope plants (using the foliar, basal bark and cut stump methods) were also determined by treating three plants within each of the following 19 basal diameter size classes (5-10, 11-20, 21-30, 31-40, 41-50, 51-60, 61-70, 71-80, 81-90, 91-100, 101-110, 111-120, 121-130, 131-140, 141-150, 151-160, 161-170, 171-180, and >180 mm).

\section{Statistical analysis}

Percentage plant mortality was subjected to an analysis of variance after an arcsine transformation and means separated by Fisher's protected least significant difference (1.s.d.) test. Height,

Table 3. Experiment A. Calotrope mortality at 737 days after treatment

Herbicides were either foliar, basal bark, cut stump or soil applied on a property located $80 \mathrm{~km}$ north-east of Normanton. Basal diameter measurements were recorded before treatment. Back-transformed means followed by a common letter within each application method do not differ significantly according to Fisher's protected 1.s.d. test $(P=0.05)$

\begin{tabular}{|c|c|c|c|c|c|}
\hline $\begin{array}{l}\text { Method of } \\
\text { application }\end{array}$ & $\begin{array}{l}\text { Herbicide (active } \\
\text { ingredient) }\end{array}$ & $\begin{array}{c}\text { Rates applied } \\
\text { (g active ingredient/ } \\
100 \mathrm{~L} \text { spray solution) }\end{array}$ & $\begin{array}{l}\text { Mortality } \\
(\%)\end{array}$ & $\begin{array}{l}\text { Basal diameter } \\
\text { range }(\mathrm{mm})\end{array}$ & $\begin{array}{l}\text { Basal diameter }(\mathrm{mm}) \\
\quad(\text { mean } \pm \text { s.e.m. })\end{array}$ \\
\hline \multirow{19}{*}{ Foliar applied } & 2,4-D/picloram & $100 / 25$ & $0 \mathrm{~d}$ & $14-82$ & \\
\hline & 2,4-D/picloram & $200 / 50$ & $17 \mathrm{c}$ & $17-96$ & \\
\hline & 2,4-D/picloram & $400 / 100$ & $27 \mathrm{c}$ & $20-127$ & \\
\hline & Clopyralid & 150 & $0 \mathrm{~d}$ & $17-85$ & \\
\hline & Clopyralid & 300 & $0 \mathrm{~d}$ & $15-64$ & \\
\hline & Clopyralid & 600 & $0 \mathrm{~d}$ & $17-100$ & \\
\hline & Dicamba & 200 & $0 \mathrm{~d}$ & $24-81$ & \\
\hline & Fluroxypyr & 150 & od & $23-78$ & \\
\hline & Fluroxypyr & 300 & $0 \mathrm{~d}$ & $27-145$ & \\
\hline & Fluroxypyr & 600 & $0 \mathrm{~d}$ & $14-65$ & \\
\hline & Imazapyr & 125 & $100 \mathrm{a}$ & $19-120$ & \\
\hline & Imazapyr & 250 & $100 \mathrm{a}$ & $9-59$ & \\
\hline & Metsulfuron-methyl & 9 & $73 b$ & $15-86$ & \\
\hline & Metsulfuron-methyl & 12 & $100 \mathrm{a}$ & $20-100$ & \\
\hline & Triclopyr/picloram & $50.1 / 16.7$ & $0 \mathrm{~d}$ & $18-72$ & \\
\hline & Triclopyr/picloram & $75 / 25$ & $0 \mathrm{~d}$ & $15-164$ & \\
\hline & Triclopyr/picloram & $150 / 50$ & $0 \mathrm{~d}$ & $18-74$ & \\
\hline & Control & - & $0 \mathrm{~d}$ & $18-96$ & \\
\hline & Mean & & & & $42.8 \pm 0.8$ \\
\hline \multirow[t]{8}{*}{ Basal bark } & 2,4-D butyl ester & 1000 & $0 \mathrm{c}$ & $11-78$ & \\
\hline & 2,4-D butyl ester & 2000 & $50 \mathrm{~b}$ & $9-83$ & \\
\hline & Fluroxypyr & 300 & $0 \mathrm{c}$ & $16-92$ & \\
\hline & Fluroxypyr & 600 & $0 \mathrm{c}$ & 13-107 & \\
\hline & Triclopyr & 480 & $40 \mathrm{~b}$ & $16-78$ & \\
\hline & Triclopyr & 960 & $90 \mathrm{a}$ & $24-74$ & \\
\hline & Control & Neat diesel & $0 \mathrm{c}$ & $18-76$ & \\
\hline & Mean & & & & $45.1 \pm 1.3$ \\
\hline \multirow[t]{9}{*}{ Cut stump } & 2,4-D butyl ester & 1000 & $0 \mathrm{~b}$ & $21-113$ & \\
\hline & 2,4-D butyl ester & 2000 & $0 \mathrm{~b}$ & $24-174$ & \\
\hline & Fluroxypyr & 300 & $0 \mathrm{~b}$ & $28-128$ & \\
\hline & Fluroxypyr & 600 & $0 \mathrm{~b}$ & $33-114$ & \\
\hline & Triclopyr & 480 & $53 a$ & $7-109$ & \\
\hline & Triclopyr & 960 & $43 a$ & $20-96$ & \\
\hline & Control & Neat diesel & $0 \mathrm{~b}$ & $24-99$ & \\
\hline & Control & Cut only, no diesel & $0 \mathrm{~b}$ & $39-86$ & \\
\hline & Mean & & & & $54.9 \pm 1.6$ \\
\hline \multirow[t]{4}{*}{ Soil applied } & Tebuthiuron & $1500 \mathrm{~g} / \mathrm{ha}$ & $20 \mathrm{a}$ & $11-154$ & \\
\hline & Tebuthiuron & $2000 \mathrm{~g} / \mathrm{ha}$ & $15 \mathrm{a}$ & $14-94$ & \\
\hline & Control & - & $0 \mathrm{~b}$ & $18-95$ & \\
\hline & Mean & & & & $47.9 \pm 2.7$ \\
\hline
\end{tabular}


basal diameter, plant density, herbicide volume and labour costs were subjected to regression analysis.

\section{Results}

Of the plants treated, $8 \%$ were single stemmed, $64 \%$ contained $2-5$ stems per plant and the remainder had $>5$ stems per plant (Fig. 1). The relationship between plant height and basal diameter was fitted with a power function $\left(\mathrm{H}=0.755 \mathrm{D}^{0.309}\right)$ which accounted for $52 \%$ of the variation in plant height (Fig. 2).

\section{Foliar applied herbicides}

Calotrope was effectively controlled (100\% kill) by the foliar herbicides imazapyr (both rates) and metsulfuron-methyl (higher rate) (Table 3) within the size classes tested. The lower rate of metsulfuron-methyl killed $73 \%$ of the treated plants. Clopyralid, dicamba, fluroxypyr, 2,4-D/picloram (lowest rate) and triclopyr/ picloram were ineffective at controlling calotrope at the rates tested, with no plants killed. The 2,4-D/picloram rate that contained $400 \mathrm{~g}$ of $2,4-\mathrm{D}$ plus $100 \mathrm{~g}$ of picloram killed $27 \%$ of the treated plants.

\section{Soil applied herbicide}

The soil applied herbicide tebuthiuron was ineffective against calotrope at the doses tested, with only $20 \%$ of plants killed at the lowest rate (Table 3).

\section{Basal bark and cut stump herbicides}

Results for the basal bark and cut stump treatments yielded different results depending on the site (Tables 3,4). Comparing the results of the two methods, plant mortality was lower for Experiment A (18\% mortality) compared to Experiment B (70\% mortality). A significantly higher $(P=0.023)$ percentage of calotrope plants were killed by the basal bark method than the cut stump method of application in Experiment A. In contrast, there was no significant difference in efficacy between the two methods in Experiment B.

A significant $(P=0.006)$ interaction was observed between method of application and herbicide treatment in Experiment A. The main factors contributing to the interaction were the herbicides triclopyr $(960 \mathrm{~g} / 100 \mathrm{~L})$ and 2,4-D butyl ester $(2000 \mathrm{~g} /$ $100 \mathrm{~L}$ ). These herbicides and rates when applied as basal bark treatments killed 90 and $50 \%$ of the plants respectively, compared with 43 and $0 \%$ when applied as cut stump treatments in Experiment A (Table 3). The $300 \mathrm{~g} / \mathrm{L}$ formulation of fluroxypyr was ineffective at controlling calotrope $(0 \%$ mortality $)$ in Experiment A.

Irrespective of herbicide and method of application, plant mortality increased with increasing herbicide concentration in Experiment B (Table 4), with herbicide treatment significant at $P<0.0005$. The higher rates of 2,4-D butyl ester, fluroxypyr and triclopyr/picloram killed 95,92 and $85 \%$ of the treated plants when applied as a basal bark method, and when applied as a cut stump method killed 99, 92 and 90\%, respectively

Table 4. Experiment B. Calotrope mortality at 556 days after treatment

Herbicides were either applied as a basal bark or cut stump method on a property located $35 \mathrm{~km}$ west of Georgetown. Basal diameter measurements were recorded before treatment. Back-transformed means followed by a common letter within each application method do not differ significantly according to Fisher's protected 1.s.d. test $(P=0.05)$

\begin{tabular}{|c|c|c|c|c|c|}
\hline $\begin{array}{l}\text { Method of } \\
\text { application }\end{array}$ & $\begin{array}{l}\text { Herbicide (active } \\
\text { ingredient) }\end{array}$ & $\begin{array}{l}\text { Rates applied (g active } \\
\text { ingredient } / 100 \mathrm{~L} \\
\text { spray solution) }\end{array}$ & $\begin{array}{l}\text { Mortality } \\
(\%)\end{array}$ & $\begin{array}{l}\text { Basal diameter range } \\
\qquad(\mathrm{mm})\end{array}$ & $\begin{array}{l}\text { Basal diameter }(\mathrm{mm}) \\
\quad(\text { mean } \pm \text { s.e.m. })\end{array}$ \\
\hline \multirow{12}{*}{ Basal bark } & 2,4-D butyl ester & 2000 & $78 a-d$ & $31-130$ & \\
\hline & 2,4-D butyl ester & 4000 & $86 a b c$ & $32-128$ & \\
\hline & 2,4-D butyl ester & 8000 & $95 \mathrm{a}$ & $32-126$ & \\
\hline & Furoxypyr & 333 & $59 \mathrm{de}$ & $29-125$ & \\
\hline & Fluroxypyr & 500 & $70 \mathrm{~b}-\mathrm{e}$ & $30-133$ & \\
\hline & Fluroxypyr & 1000 & $92 \mathrm{ab}$ & $31-132$ & \\
\hline & Triclopyr/picloram & $100 / 50$ & $68 \mathrm{cde}$ & $27-143$ & \\
\hline & Triclopyr/picloram & $200 / 100$ & $87 \mathrm{abc}$ & $28-137$ & \\
\hline & Triclopyr/picloram & $400 / 200$ & $85 a-d$ & $28-134$ & \\
\hline & Control & Neat diesel & $47 \mathrm{e}$ & $25-148$ & \\
\hline & Control & No diesel & $1 \mathrm{f}$ & $21-166$ & \\
\hline & Mean & & & & $69.3 \pm 0.9$ \\
\hline \multirow[t]{12}{*}{ Cut stump } & 2,4-D butyl ester & 2000 & $67 \mathrm{cde}$ & $31-132$ & \\
\hline & 2,4-D butyl ester & 4000 & $85 \mathrm{bcd}$ & $31-130$ & \\
\hline & 2,4-D butyl ester & 8000 & $99 a$ & $32-127$ & \\
\hline & Fluroxypyr & 333 & $76 b-e$ & 29-134 & \\
\hline & Fluroxypyr & 500 & $82 \mathrm{bcd}$ & $30-134$ & \\
\hline & Fluroxypyr & 1000 & $92 \mathrm{ab}$ & $30-133$ & \\
\hline & Triclopyr/picloram & $100 / 50$ & 63de & $27-143$ & \\
\hline & Triclopyr/picloram & $200 / 100$ & $79 \mathrm{bcd}$ & $27-141$ & \\
\hline & Triclopyr/picloram & $400 / 200$ & $90 a b c$ & $28-137$ & \\
\hline & Control & Neat diesel & $48 \mathrm{e}$ & $23-155$ & \\
\hline & Control & Cut only, no diesel & $8 \mathrm{f}$ & $21-161$ & \\
\hline & Mean & & & & $69.5 \pm 0.9$ \\
\hline
\end{tabular}




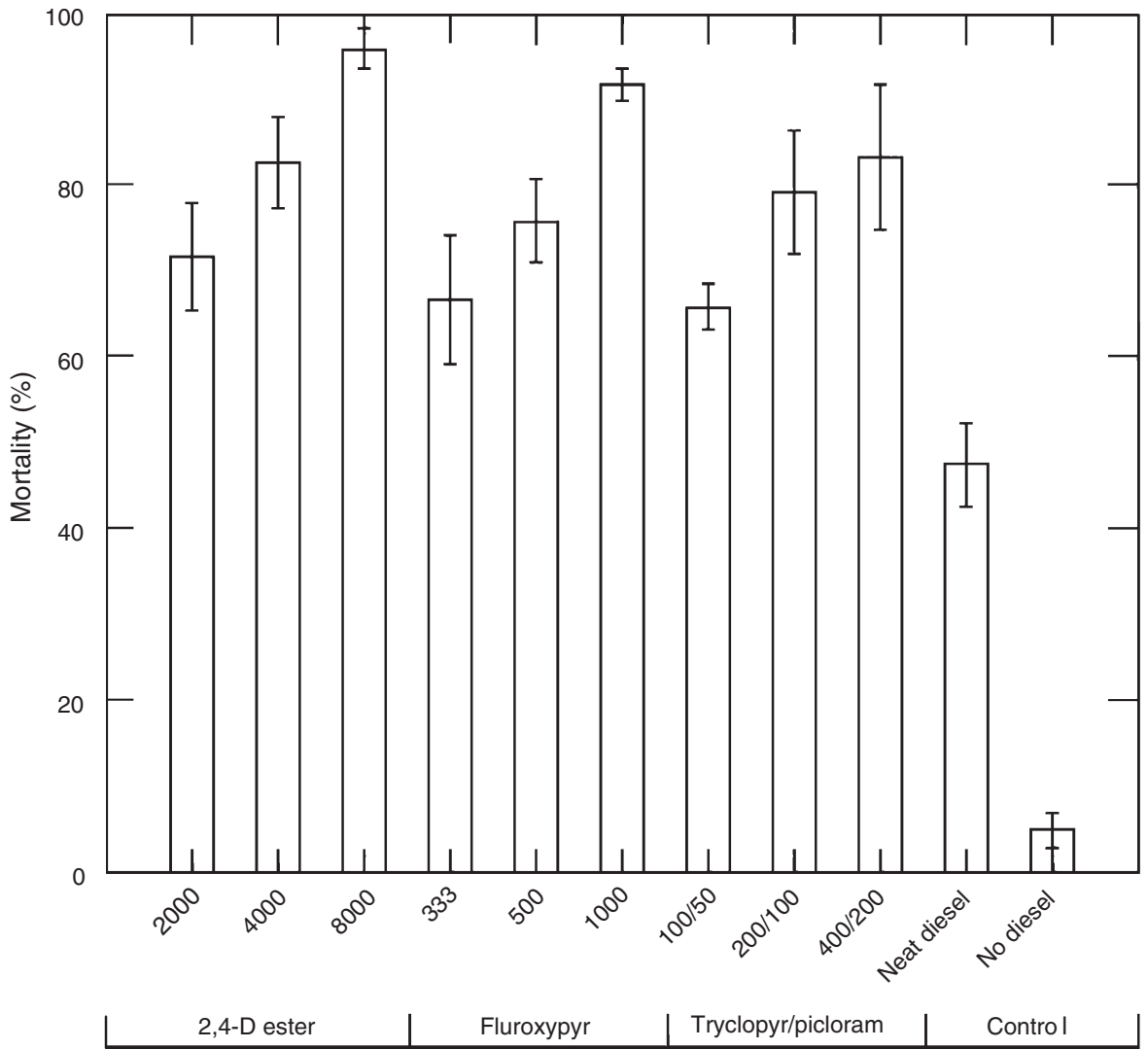

Herbicide treatment (g a.i. per $100 \mathrm{~L}$ diesel)

Fig. 3. Experiment B. Calotrope mortality at 556 days after treatment, irrespective of method of application (basal bark or cut stump), on a property located $35 \mathrm{~km}$ west of Georgetown. Vertical bars indicate the s.e. of the means.

(Table 4). Irrespective of the method of application, 2,4-D butyl ester $(8000 \mathrm{~g} / 100 \mathrm{~L})$ was the most effective herbicide, killing an average of $97 \%$ of the treated calotrope plants, followed by fluroxypyr (1000 g/100 L) which killed $92 \%$ of the plants (Fig. 3). Kills of $80 \%$ or greater were also obtained with triclopyr/picloram $(200 / 100 \mathrm{~g}$ and $400 / 200 \mathrm{~g} / 100 \mathrm{~L}$ ) (for basal bark), 2,4-D butyl ester ( $4000 \mathrm{~g} / 100 \mathrm{~L})$ (for basal bark and cut stump), fluroxypyr $(500 \mathrm{~g} / 100 \mathrm{~L})$ (for cut stump) and triclopyr/picloram (400/200 g/100 L) (for cut stump).

There was no significant effect of basal diameter size class on plant mortality irrespective of method of application (Fig. 4) or within each method of application irrespective of herbicide treatment.

\section{Treatment costs}

November 2007 retail prices were used to determine the cost of $100 \mathrm{~L}$ of spray solution and ranged from $\$ 5.33$ to $\$ 298.87$ (Table 2) depending on the herbicide and dose rate. Prices were based on purchases of the largest commercial size readily available.

The volume of herbicide mix required to treat a calotrope plant of a specific basal diameter (BD) by a particular method of application was calculated using the following equations, which were derived from regression analysis on the basal diameter size class data:

Foliar spray using $12 \mathrm{~V}$ motor, $y=0.00248 \mathrm{BD} \ln (\mathrm{BD})$,

$$
\left(R^{2}=0.61\right)
$$

Basal bark spraying, $y=0.00177 \mathrm{BD},\left(R^{2}=0.85\right)$, and

Cut stump spraying, $y=0.00189 \mathrm{BD}^{0.6688},\left(R^{2}=0.62\right)$

As a working example, a calotrope plant with a $100 \mathrm{~mm}$ basal diameter would require 1142, 177 and $41 \mathrm{~mL}$, respectively, when treated by foliar, basal bark and cut stump methods (Fig. 5). Based on the 2007 prices, the herbicide used to treat the $100 \mathrm{~mm}$ basal diameter plant using the most cost effective herbicides would, respectively, cost $\$ 0.07^{1}, \$ 0.32$ and $\$ 0.07$ (assuming metsulfuron-methyl $(12 \mathrm{~g}$ a.i./100 L) was used as the foliar herbicide spray and triclopyr/picloram (200/100 g a.i./100 L) as the basal bark/cut stump spray).

${ }^{1}$ All values in Australian dollars. 


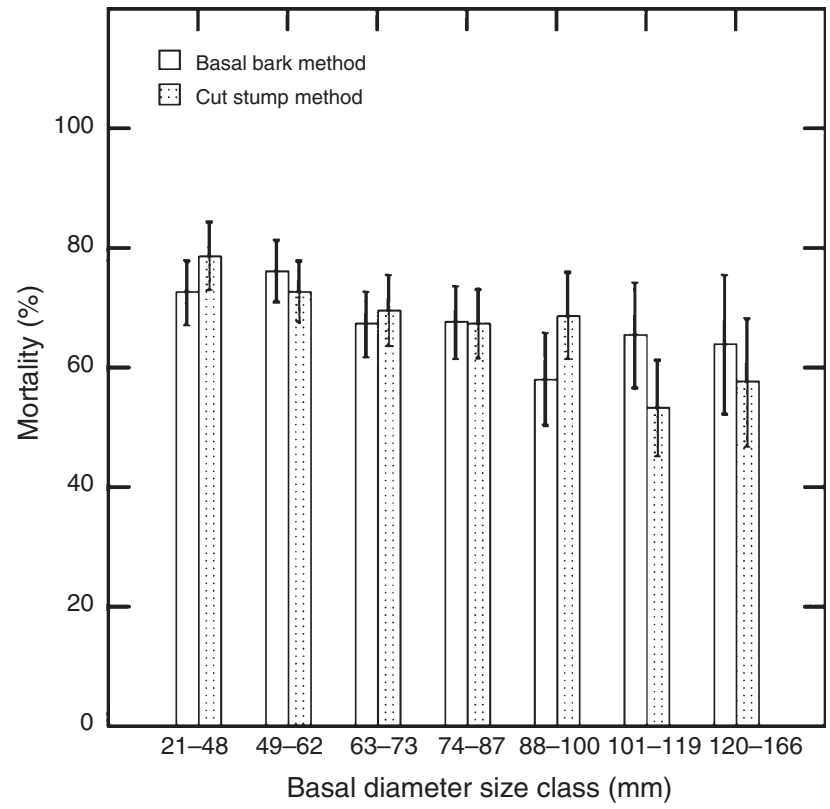

Fig. 4. Experiment B. Effect of basal diameter on calotrope mortality at 556 days after treatment, irrespective of herbicide treatment on a property located $35 \mathrm{~km}$ west of Georgetown. Vertical bars indicate the s.e. of the means.

The cost (labour plus spray mix) of a single chemical application to treat a calotrope density of 1600 plants/ha based on the regression equations (Table 5) would be \$543, \$274, \$235 and $\$ 99 /$ ha, respectively, using the chemical control methods of basal bark spraying, cut stump spraying, foliar spraying and soil applied. Conversely, to treat a density of 100 plants/ha it would, respectively, cost $\$ 85, \$ 43, \$ 59$ and $\$ 25$ (Fig. 6). Labour is calculated at $\$ 20 / \mathrm{h}$, diesel at $\$ 1.24 / \mathrm{L}$ and the herbicides selected were metsulfuron-methyl $(12 \mathrm{~g}$ a.i./100 L) (foliar herbicide spray), triclopyr/picloram (200/100 g a.i./100 L) (basal bark/cut stump spray) and tebuthiuron $\left(0.15 \mathrm{~g}\right.$ a.i. $\left./ \mathrm{m}^{2}\right)$ (soil applied). Soil application using tebuthiuron, though the cheapest method, is not effective against calotrope. The time required to treat varying calotrope densities using the foliar, cut stump and basal bark

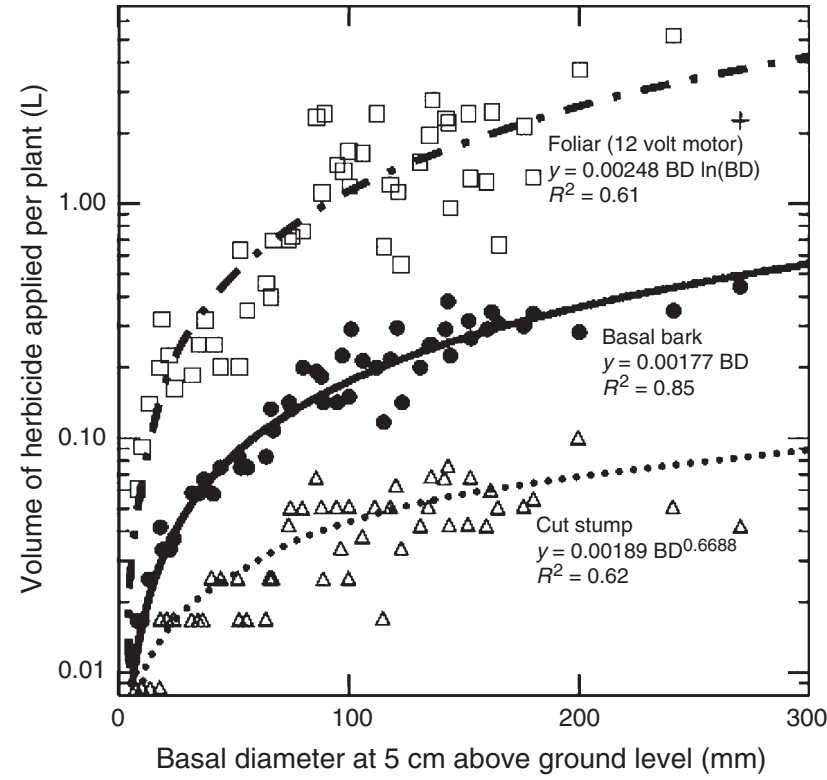

Fig. 5. Volume of herbicide (L) applied per calotrope plant based on basal diameter and method of application. $\exists$ Foliar (12 V motor), basal bark, $\Delta$ cut stump method.

spraying application methods (Fig. 6) was very similar $(P=0.076)$, with no significant difference observed between foliar and cut stump spraying. The volume of herbicide required to treat calotrope using the three most effective methods of application was significant at the $P<0.005$ level (Fig. 6). Excluding the soil applied method, cut stump and foliar spraying are the most cost effective methods for controlling calotrope densities <800 plants/ha (Fig. 6).

\section{Discussion}

The field experiments indicated that of the 11 herbicides tested, the basal bark/cut stump applied herbicides 2,4-D butyl ester, fluroxypyr, triclopyr and triclopyr/picloram were capable of killing $80 \%$ or more of the treated calotrope plants

Table 5. Equations of best fit and coefficients of determination $\left(R^{2}\right)$ for relationships between volume of herbicide applied (L/ha), time to apply herbicide (hours/ha) and cost, against varying calotrope densities (plants/ha), using four different methods of herbicide application

\begin{tabular}{|c|c|c|c|}
\hline Variable & Method of application & Equation & $R^{2}$ \\
\hline Volume of herbicide applied (L/ha) & $\begin{array}{c}\text { Foliar } \\
\text { Basal bark } \\
\text { Cut stump } \\
\text { Soil applied }\end{array}$ & $\begin{array}{l}y=18.788 x^{0.5} \\
y=0.716 x^{0.5} \ln (x) \\
y=0.126 x^{0.5} \ln (x) \\
y=x^{0.649}\end{array}$ & $\begin{array}{l}0.44 \\
0.69 \\
0.77 \\
0.92\end{array}$ \\
\hline Time to apply herbicide $(\mathrm{h} / \mathrm{ha})$ & $\begin{array}{c}\text { Foliar } \\
\text { Basal bark } \\
\text { Cut stump } \\
\text { Soil applied }\end{array}$ & $\begin{aligned} y & =0.236 x^{0.55} \\
y & =0.279 x^{0.5} \ln (x) \\
y & =0.233 x^{0.5} \\
y & =0.028[\ln (x)]^{2}\end{aligned}$ & $\begin{array}{l}0.50 \\
0.77 \\
0.73 \\
0.76\end{array}$ \\
\hline Combined cost of labour and herbicide mix $(\$ / \mathrm{ha})^{\mathrm{A}}$ & $\begin{array}{c}\text { Foliar } \\
\text { Basal bark } \\
\text { Cut stump } \\
\text { Soil applied }\end{array}$ & $\begin{array}{l}y=5.881 x^{0.5} \\
y=1.84 x^{0.5} \ln (x) \\
y=0.927 x^{0.5} \ln (x) \\
y=2.482 x^{0.5}\end{array}$ & $\begin{array}{l}0.49 \\
0.72 \\
0.76 \\
0.90\end{array}$ \\
\hline
\end{tabular}

\footnotetext{
${ }_{\mathrm{A}}^{\mathrm{A}}$ Labour is calculated at $\$ 20 / \mathrm{h}$, diesel at $\$ 1.24 / \mathrm{L}$ and the herbicides selected were metsulfuron-methyl $(12 \mathrm{~g}$ a.i./100 L) (foliar herbicide spray), triclopyr/picloram (200/100 g a.i./100 L) (basal bark/cut stump spray) and tebuthiuron $\left(0.15 \mathrm{~g}\right.$ a.i. $\left./ \mathrm{m}^{2}\right)$ (soil applied).
} 


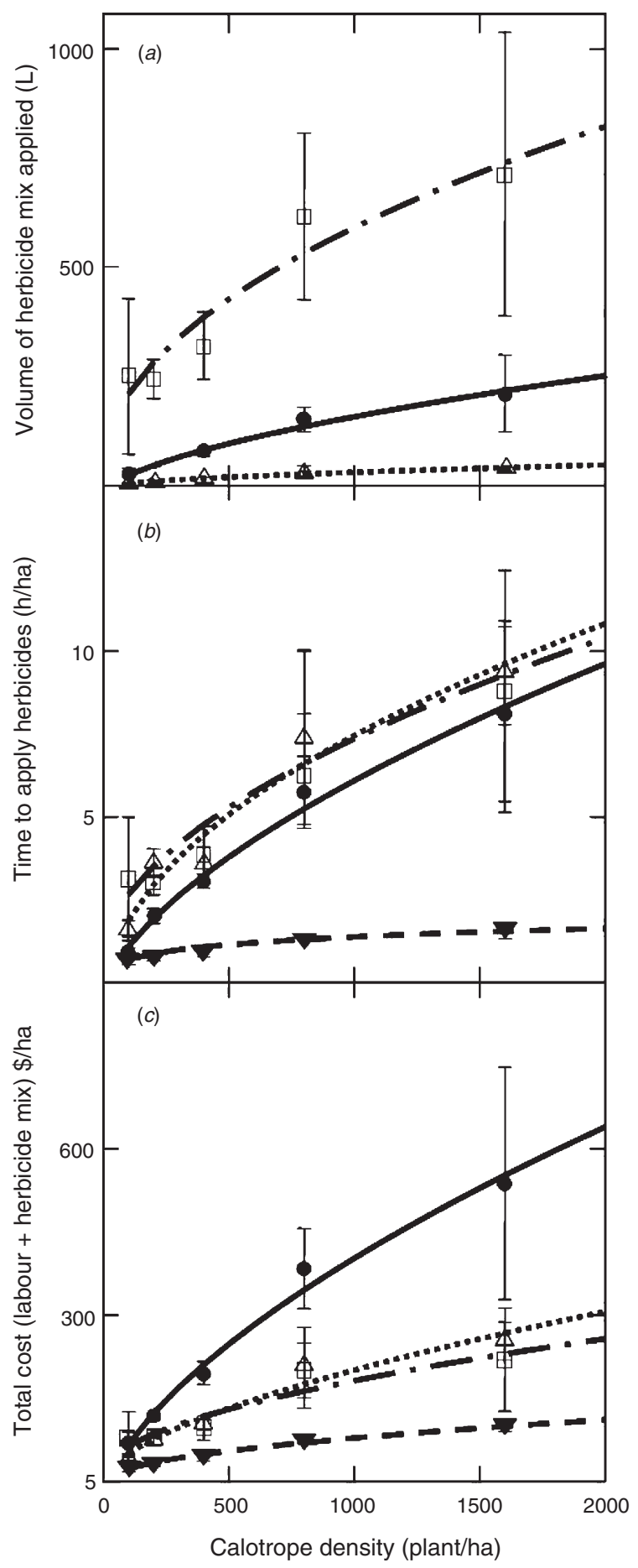

Fig. 6. Relationships between $(a)$ volume of herbicide solution applied (L/ha) (soil applied herbicide in $\mathrm{g} / \mathrm{ha}$, not included in graph), (b) time to apply herbicide (hours/ha), and (c) cost (AU\$/ha, prices November 2007), against varying calotrope densities (plants/ha), using four different methods of herbicide application ( $\bullet$ basal bark, $\triangle$ cut stump, $\boxminus$ foliar (12 V battery) and * soil applied).

and the application of the foliar applied herbicides imazapyr and metsulfuron-methyl resulted in $100 \%$ mortality. Based on the cost of application, metsulfuron-methyl $(12 \mathrm{~g}$ a.i./ $100 \mathrm{~L}$ at a cost of $\$ 6.15 / 100 \mathrm{~L}$ spray mix) and triclopyr/picloram (200/100 g a.i./ $100 \mathrm{~L}$ at a cost of $\$ 179.09 / 100 \mathrm{~L}$ spray mix) are, respectively, the preferred foliar and basal bark/cut stump herbicides for controlling calotrope. The soil applied herbicide tebuthiuron was ineffective at controlling calotrope at the rates tested.

The trial identified three effective herbicide control options, namely foliar, basal bark and the cut stump method of application. The cut stump method, however, yielded varying results depending on the experiment. Results ranged from 0 to $53 \%$ in Experiment $\mathrm{A}$ and 48 to $99 \%$ mortality in Experiment B. The difference in mortality could be attributed to the height the plants were cut above ground level $(20 \mathrm{~cm}$ in Experiment $\mathrm{A}$ and $5 \mathrm{~cm}$ in Experiment $\mathrm{B}$ ) before the application of herbicide. Other researchers (Carmona et al. 2001) have observed a decline in efficacy with increasing height of stem cutting before the application of herbicides. Carmona et al. (2001) recorded a $31-86 \%$ reduction in efficacy for Acacia farnesiana and a $63-90 \%$ reduction in efficacy for Mimosa pteridofita when the plants were cut at $20 \mathrm{~cm}$ compared with $0 \mathrm{~cm}$ above ground level, before the application of 2,4-D/picloram (9.6/2.56 g a.i./L diesel). In this trial, 2,4-D butyl ester $(2000 \mathrm{~g}$ a.i./100 L) killed $67 \%$ of the plants treated when cut $5 \mathrm{~cm}$ above ground and $0 \%$ when the plants were cut $20 \mathrm{~cm}$ above ground level, before herbicide application. These results suggest that plants should be cut as close to ground level as possible before the application of herbicides if the cut stump method is to be used.

In any weed control program, the density of the infestations should help decide the control methods used. Herbicides are generally used where the density of weeds is low to medium (Vitelli 2000). In dense infestations of calotrope, mechanical control such as an Ellrott plough (front mounted blade plough) or a rear mounted blade plough, where $25-30 \mathrm{~cm}$ of the taproot is uprooted, may be more cost effective. Dense infestations of parkinsonia (2200 plants/ha) were effectively controlled with an Ellrott plough (93\% mortality) and a rear mounted blade plough (91\% mortality) (McKenzie et al. 2004) at costs of $\$ 175$ and \$220/ha, respectively, adjusted to 2007 prices (J. R. McKenzie, pers. comm.). Based on our trial, $\$ 175 /$ ha would treat 285 , 800 , and 885 calotrope plants/ha using the respective control methods of basal bark, cut stump and foliar spraying. In terms of cost effectiveness, chemical control (cut stump and foliar spraying) would be the most appropriate tool to control calotrope densities $<800$ plants/ha. Control costs given are always approximate and may change due to factors such as terrain or operator variability.

Adoption of pasture management practices that promote perennial grasses in calotrope infested paddocks, coupled with strategic chemical control (targeting scattered calotrope plants), could be an effective and economical way of controlling vast areas of calotrope. To better understand the processes and causes of calotrope invasion and the control options necessary to mitigate its continued expansion, long-term studies (5-8 years) are needed, combining chemical, fire, mechanical and pasture management options with an understanding of the plant's biology. The derived recommendations must be practical, affordable, environmentally sound and capable of being implemented across the vast areas of northern Australia. 


\section{Acknowledgments}

We thank the Queensland Department of Primary Industries \& Fisheries for financial support. The authors would like to thank Carl Andersen, Andrew Beattie, Dannielle Brazier, William Dorney, Peter James, Tanya Robinson, Catherine Setter, Dr Wayne Vogler and Alan Smith (Etheridge Shire) for their technical assistance and Drs Shane Campbell and Dane Panetta for their constructive comments on the manuscript.

\section{References}

Abbas, B., Eltayeb, A. E., and Sulleiman, Y. R. (1992). Calotropis procerafeed potential for arid zones. The Veterinary Record 131, 132.

Bastin, G. N., Ludwig, J. A., Eager, R. W., Liedloff, A. C., Andison, R. T., and Cobiac, M. D. (2003). Vegetation changes in a semiarid tropical savanna, northern Australia: 1973-2002. The Rangeland Journal 25, 3-19. doi: $10.1071 /$ RJ03001

Bureau of Meteorology (2007). Climate Data Online. Available at: www.bom. gov.au/climate/averages/ (accessed 30 October 2007).

Carmona, R., Neto, S. B. C. A., and Pereira, R. C. (2001). Control of Acacia farnesiana and of Mimosa pteridofita in pastures. Pesquisa Agropecuaria Brasileira 36, 1301-1307.

Cheam, A. H. (1984a). Allelopathy in buffel grass (Cenchrus ciliaris L.). Part I. Influence of buffel grass association on calotrope (Calotropis procera (Ait.) W.T. Ait.). Australian Weeds 3, 133-136.

Cheam, A. H. (1984b). Allelopathy in buffel grass (Cenchrus ciliaris L.) Part II. Site of release and distribution of allelochemical in the soil profile. Australian Weeds 3, 137-139.

Clarke, P. J., Latz, P. K., and Albrecht, D. E. (2005). Long-term changes in semi-arid vegetation: Invasion of an exotic perennial grass has larger effects than rainfall variability. Journal of Vegetation Science 16, 237-248. doi: 10.1658/1100-9233(2005)016[0237:LCISVI]2.0.CO;2

Ellison, C. A., and Barret, R. W. (2004). Prospects for the management of invasive alien weeds using co-evolved fungal pathogens: a Latin American perspective. Biological Invasions 6, 23-45. doi: 10.1023/ B:BINV.0000010118.36571.ef

Foran, B. D., Bastin, G., and Hill, B. (1985). The pasture dynamics and management of two rangeland communities in the Victoria River District of the Northern Territory. Australian Rangeland Journal 7, 107-113. doi: 10.1071/RJ9850107
Grace, B. S. (2006). The biology of Australian weeds 45. Calotropis procera (Aiton) W.T.Aiton. Plant Protection Quarterly 21, 152-160.

Jackson, J. (2005). Is there a relationship between herbaceous species richness and buffel grass (Cenchrus ciliaris)? Austral Ecology 30, 505-517. doi: $10.1111 / \mathrm{j} .1442-9993.2005 .01465 . \mathrm{x}$

McIvor, J. G. (2003). Competition affects survival and growth of buffel grass seedlings - is buffel grass a coloniser or an invader? Tropical Grasslands 37, 176-181.

McKenzie, J. R., Pattison, M. J., Steele, K. E., Campbell, S. D., and Vitelli, J. S. (2004). Controlling dense infestations of parkinsonia (Parkinsonia aculeata L.). In: 'Proceedings of the 14th Australian Weeds Conference'. Wagga Wagga, NSW. (Eds B. M. Sindel and S. B. Johnson.) pp. 176-178. (Weed Society of New South Wales: Wahroonga, NSW.)

Meadley, G. R. W. (1971). Calotropis, or rubber tree (Calotropis procera (Linn.) Dryand.). Journal of Agriculture, Western Australia 12, 69-71.

O'Donnell, C., and Adkins, S. W. (2005). Management of parthenium weed through competitive displacement with beneficial plants. Weed Biology and Management 5, 77-79. doi: 10.1111/j.1445-6664.2005.00160.x

Parsons, W. T., and Cuthbertson, E. G. (2001). 'Noxious Weeds of Australia.' (CSIRO Publishing: Melbourne.)

Radunz, B. L., Wilson, G., and Beere, G. (1984). Feeding rubberbush (Calotropis procera) to cattle and sheep. Australian Veterinary Journal 61, 243-244. doi: 10.1111/j.1751-0813.1984.tb06006.x

Rahman, M. A., and Wilcock, C. C. (1991). A taxonomic revision of Calotropis (Asclepiadaceae). Nordic Journal of Botany 11, 301-308. doi: 10.1111/j.1756-1051.1991.tb01408.x

Thorp, J. R., and Lynch, R. (2000). 'The Determination of Weeds of National Significance. National Weeds Strategy Executive Committee.' (Department of Agriculture, Fisheries and Forestry: Launceston, Tas.)

Vitelli, J. S. (2000). Options for effective weed management. Tropical Grasslands 34, 280-294.

Wilkinson, P. M., Thomas-Hall, S., Marney, T. S., and Shivas, R. G. (2005). First record of Passalora calotropidis in Australia and its generic position. Australasian Plant Pathology 34, 95-98. doi: 10.1071/AP04074

Manuscript received 15 November 2007; accepted 16 May 2008 